\title{
The Use of Technical Analysis by Fund Managers: International Evidence
}

\author{
Lukas Menkhoff \\ Discussion Paper No.466 \\ April 2010 \\ ISSN 0409-9962
}

\begin{abstract}
The use of technical analysis by financial market professionals is not well understood. This paper thus analyzes survey evidence from 692 fund managers in five countries, the vast majority of whom rely on technical analysis. At a forecasting horizon of weeks, technical analysis is the most important form of analysis and up to this horizon it is thus more important than fundamental analysis. Technicians are as experienced, as educated, as successful in their career and largely just as overconfident in decision-making as others. However, technical analysis is somewhat more popular in smaller asset management firms. What we find most significant is the relation of technical analysis with the view that prices are heavily determined by psychological influences. Consequently, technicians apply trend-following behavior.
\end{abstract}

JEL-Classification: $\quad$ G 14 (information), G 23 (fund management)

Keywords: $\quad$ fund managers, technical analysis, fundamental analysis, personal characteristics, investment behavior

* I thank all the participating fund managers for taking time either in interviews or in answer-
ing the questionnaire. Moreover, I thank the investment management associations of Germany
(Bundesverband BVI), Italy and Thailand as well as Michael Melvin for their generous sup-
port in conducting the survey study and an anonymous referee for valuable comments. Great
research assistance was provided by Fabian Bätje, Daniela Beckmann, Oliver Gloede, Torben
Lütje and Marina Nikiforow. Financial support by the Volkswagen Foundation is gratefully
acknowledged.

Lukas Menkhoff, Department of Economics, Leibniz Universität Hannover, Königsworther Platz 1, D-30167 Hannover, Germany, menkhoff@gif.uni-hannover.de 


\section{The Use of Technical Analysis by Fund Managers: International Evidence}

\section{$1 \quad$ Introduction}

Some decades ago, the use of technical analysis was heavily debated in academia (see Fama, 1970). Since then, however, modern capital market theory has revolutionized fund management, seemingly taking the grounds away for non-fundamental analyses. So it may be puzzling that even a superficial contact with real world fund management already reveals the survival of a prominent non-fundamental kind of analysis, i.e. technical analysis. Interestingly, in academia, forms of this analysis are also seriously analyzed, as shown by articles in leading journals. ${ }^{1} \mathrm{We}$ can thus conclude that technical analysis is still an issue in financial markets, both in practice and in academia. In contrast to this relevance, however, according to our knowledge, there is no systematic information about the use of technical analysis in fund management. How important is technical analysis nowadays, how do professionals use it and why do professionals use it at all? This paper provides evidence on these questions, based on a broad survey study conducted with 692 fund managers in five markets, namely the US, Germany, Switzerland, Italy and Thailand.

We have deliberately chosen to use data about fund managers in our examination of the use of technical analysis for two reasons. First, fund managers have evolved as the most important group in modern financial markets when it comes to holdings and transactions (Davis and Steil, 2001), so they are of undisputed empirical importance when it comes to understanding real world markets. Second, fund managers are-in contrast to individual investorshighly qualified market participants; this exempts them from any concerns about a lack of professionalism. Accordingly, if there is evidence that technical analysis plays a significant role in their decision making, this finding is not rooted in the examination of a dubious or marginal group. On the contrary, a use of technical analysis by fund managers would be an important factor to be considered when attempting to reach an appropriate theoretical understanding of financial markets.

\footnotetext{
${ }^{1}$ To mention some examples: Brock, Lakonishok and LeBaron (1992), Blume, Easley and O'Hara (1994), Lo, Mamaysky and Wang (2000), Kavajecz and Odders-White (2004), Nam, Washer and Chu (2005), Kliger and Kudryavtsev (2008), Friesen, Weller and Dunham (2009), Harris and Yilmaz (2009) or Zhu and Zhou (2009).
} 
We find that technical analysis is highly important as an information category. The share of fund managers that put at least some importance on technical analysis is very large at $87 \%$ and a major group (18\%) even generally prefers it to other ways of information processing. Nevertheless, technical analysis does not dominate the decision-making of fund managers in general. Fundamental analysis gets the highest relative importance at $68 \%$ as compared to $22 \%$ for technical analysis and $10 \%$ for flows (equal weighting of countries). When we focus on forecasting horizons, however, we find that technical analysis is the most important form of analysis for decisions with forecasting horizons of some weeks, dominating fundamental analysis up to this horizon. So, technical analysis is obviously in wide-spread and relevant use among fund managers. ${ }^{2}$ Given this unexpected fact—from the view of conventional capital market theory-what may the motivation for the application of technical analysis be?

We structure our examination of possible motivations according to three major positions that can be stated with reference to the efficient market hypothesis (EMH) and which are subsequently introduced at length in Section 3. According to position 1, arguing from the viewpoint of efficient financial markets, technical analysis is seen as a sign of less than fully rational behavior. A somewhat modified EMH-view, our position 2, argues that the use of technical analysis may be a rational response to high information costs. Finally, we reduce the understanding of efficient markets to its minimum condition, i.e. the absence of strategies that generate systematic excess returns, our position 3. According to this position, heterogeneous agents possess different sets of information or different beliefs about market processes, the use of technical analysis being a sign of this heterogeneity.

We test these three positions by relating the intensity of the use of technical analysis to fund managers' answers to respective items of the survey. Evidence supports position 3, somewhat supports position 2 but does not support position 1 . In order to test position 1, i.e., users of technical analysis are irrational, we relate the use of technical analysis to personal indicators of fund managers, such as experience or the degree of education-without any significant findings. The same non-result is found when we use-for the first time in this literature-indicators of overconfidence in order to test whether users of technical analysis are inferior to non-users. So there is no evidence that technical analysis is preferred by less rational or otherwise inferior fund managers, which is in line with findings from foreign exchange (e.g. Menkhoff, 1998; Cheung, Chinn and Marsh, 2004). Our most interesting result with respect to

\footnotetext{
${ }^{2}$ The structural information fits well to results from foreign exchange but the overall level is higher in foreign exchange with a share of more than 30\% (see Menkhoff and Taylor, 2007).
} 
position 2 is the fact that technical analysis is more heavily used in smaller fund management firms. As these firms have less capacity to conduct or to buy first-class fundamental research, technical analysis may serve as a second best (cheaper) form of analysis. Finally, regarding position 3, we obtain strong results again, indicating that users of technical analysis share a view about financial markets that is different from non-users. They seem to believe that psychological factors are important and that herding is beneficial. ${ }^{3}$ Users of technical analysis consequently react to this view with trend-following behavior (and also by relying more strongly on momentum and contrarian investment strategies).

The remainder of the paper is structured into seven more parts. Section 2 refers our examination of technical analysis to related literature. Section 3 leads into the above-mentioned three positions that guide our discussion. Section 4 presents the data that have been compiled for this study. Section 5 describes the international evidence with respect to the importance of using technical analysis by fund managers. Possible motivations for the important role of technical analysis are analyzed in Sections 6 and 7. Section 8 concludes.

\section{Literature}

The questions whether and, possibly, why fund managers use technical analysis have not been often directly examined before. Therefore, we want to relate our study to literature which indeed provides two motivating lines of research—-theoretical and empirical.

From the theoretical side of financial market research, the mainstream models of asset pricing, such as the CAPM, are equilibrium models which do not care much about the process towards an equilibrium (see the Grossman and Stiglitz, 1980, information paradox). Whenever such a process involves a time-consuming path from one equilibrium to another, a chance to learn efficiently by observing prices and by employing technical analysis for this purpose may evolve (Hellwig, 1982; Treynor, 1985; Brown and Jennings, 1989).

The potential usefulness of technical analysis is even more evident if financial market prices are influenced by non-fundamental behavior, a reasoning which is modeled for example in noise trading models (e.g. De Long et al., 1990). Assuming that non-fundamental behavior is not chaotic but has a systematic component (as behavioral finance does, e.g. Hirshleifer, 2001; Shiller, 2003), technical analysis may be an instrument to appropriately analyze this component. Whereas technical analysis may occur in the general noise trader models, it is a

\footnotetext{
${ }^{3}$ Again, the relation of using technical analysis with believing in an important role of psychology in financial markets is found in foreign exchange too (see Taylor and Allen, 1992).
} 
crucial ingredient in the more specific chartist-fundamentalist models, such as Frankel and Froot (1990), Brock and Hommes (1998) or De Grauwe and Grimaldi (2006). These models assume that market participants either prefer chartism (i.e. technical analysis) or fundamentalism (i.e. fundamentalist analysis) and that they may switch between both kinds of analysis according to the profitability of these trading strategies in the preceding period. Simulations of such models create complex price dynamics with outcomes similar to real world financial markets. It is an interesting implication of the chartist-fundamentalist approach that both groups will co-exist and can make money, i.e. also users of technical analysis.

The second line of literature motivating our research is evidence that technical analysis may indeed play a relevant role in fund managers' decision making. A prominent example is the recent debate about momentum trading, i.e., a mechanical investment strategy whose calculus is solely based on past asset returns (e.g. Jegadeesh and Titman, 2001; Griffin, Ji and Martin, 2003; Li et al., 2008). Grinblatt, Titman and Wermers (1995) found for example that most US mutual funds behave in a way consistent with momentum trading. So, backwardlooking investment behavior may be a common practice. ${ }^{4}$ Interestingly, and in contrast to the scarcity of evidence on the use of technical analysis in fund management, there is plenty of evidence on its use by traders in a particular financial market, the foreign exchange market. ${ }^{5} \mathrm{~A}$ reasonable explanation for this difference may be-as we see later-that technical analysis is even more important in foreign exchange.

\section{Positions}

We have structured the examination into the use of technical analysis by fund managers and their possible motivation for doing so according to three positions already briefly mentioned in the introduction. These positions are stated with reference to the efficient market hypothesis (EMH) and are developed in the following.

With reference to Fama's (1970) seminal contribution, one might be tempted to say that any use of technical analysis should be taken-in the present world of quite efficient markets-as a sign of limited rationality. Accordingly, there are fully rational users of fundamental analysis and less rational users of technical analysis. Due to their limited rationality, the

\footnotetext{
${ }^{4}$ This is supported by some survey evidence from studies conducted in Germany; see Menkhoff (1998) for fund managers with an international investment focus, Arnswald (2001) for equity fund managers and Menkhoff, Schmidt and Brozynski (2006) for fund managers in equities and bonds.
} 
latter will generate below market returns. This is clearly one way of looking at the widespread use of technical analysis and we have named this our position 1. However, the finding that most fund managers use this instrument and that it is most important for shorter-term decision-making definitely raises concerns as to whether outright irrationality will be the main motivation of professionals for using technical analysis.

In order to overcome the simplistic identification of technical analysis with inefficiency, it seems helpful to remember the origin of efficient markets, i.e., the power of competitive market forces to arbitrage (risk-adjusted) excess returns away (Malkiel, 2003). The mentioning of excess returns implies the reference to a "normal" market return and the size of this return follows from the appropriate market model. If we allow for the possibility that there is not an undisputed fundamental equilibrium model — and there is a thorough discussion of what this model should look like- then we cannot exclude the possibility that technical analysis may be a rational tool for understanding financial markets. This perspective basically reduces the implication of market efficiency here to the condition that technical analysis should not systematically generate excess returns, but allows for the possibility that the use of technical analysis may yield returns similar in size to "normal" market returns. ${ }^{6}$

This back-to-the-roots emphasis of efficient markets allows an understanding of the use of technical analysis that does not automatically imply inefficiency: Technical analysis can be a rational response to high information costs of fundamental analysis, which we have named position 2. According to this position, heterogeneity of market participants is generated by their different level of information quality (about fundamentals). As a consequence of information differences, technical trading may yield lower returns than fundamental strategies before considering information costs but similar returns afterwards. Table 1 summarizes characteristics of the positions 1 and 2 so far introduced and allows for an easy comparison between them. This table also considers position 3.

Technical analysis may rationally reflect the fact that there is heterogeneous information processing in the market, which we have named position 3 . This heterogeneity may be due to the fact that market participants possess different items of information-not different quality

\footnotetext{
${ }^{5}$ Studies include Taylor and Allen (1992) on the UK, Menkhoff (1998) on Germany, Cheung and Wong (2000) on Asian markets, Cheung and Chinn (2001) on the US and Cheung, Chinn and Marsh (2004) on the UK.

${ }^{6}$ It seems noteworthy in this respect that studies examining the risk-adjusted profitability of technical analysis often find some value in following such strategies and that the critical issue is about returns in excess of the regular market return (Park and Irwin, 2007). A good example seems to be the debate about returns to momentum strategies.
} 
levels as in position 2-or due to different ex ante beliefs about the right model, etc. The first kind of heterogeneity, i.e. differences in information, can lead to a price discovery process during which technical analysis may be a proper instrument to reveal superior knowledge and thus to partially anticipate price development in the sense of Hellwig (1982) and others. The second kind of heterogeneity, i.e. differences in beliefs, can lead to groups of market participants who are each characterized by their particular behavior. Pronounced examples of modeling such kind of heterogeneity are chartist-fundamentalist-models, as introduced in Section 2 above.

Obviously, the chartist-fundamentalist models are very closely related to position 3 . Both, that is the theoretical models as well as our more unspecific position, build on the idea that there is heterogeneity and that the use of technical analysis is part of this heterogeneity. As we will show in Section 5 below, fund managers do indeed rely to a remarkable degree on technical analysis and related trading strategies, which is consistent with the chartistfundamentalist approach. However, due to our kinds of data, we analyze cross-sectional relations, whereas the chartist-fundamentalist approach basically refers to a time-series view. In this sense, this approach reaches beyond our study. We simply provide direct information about fund managers' behavior and thus lend credibility to the chartist-fundamentalist approach.

Accepting that there are chartists in the market, their behavior may influence the market outcome, as for example investigated by Schulmeister (2007). According to this argument, technical analysis may have a self-fulfilling character. This possibility becomes more relevant when the share of chartists is high and when counter-balancing forces are weak. We cannot make a judgment on these conditions. Whatever the case, however, the outcome will be consistent with position 3 .

Overall, this paper takes the three positions as given and examines whether the use of technical analysis by fund managers shows empirical patterns which are more or less consistent with each of these positions.

\section{Data}

The data for this research are taken from a questionnaire survey conducted in 2003/04 in Germany, Switzerland, United States, Italy and Thailand—in the order of data compilation. We show that the data set provides reliable information and is largely representative for fund managers in these countries. 
The reason why we have conducted this survey is straightforward: There is no available systematic information on the use of technical analysis by fund managers which we could analyze and there is no alternative method of getting this information than conducting a survey. We are aware of objections to the survey approach and share the view that "revealed preferences" by trading data are superior to possible "cheap talk". However, this is not the choice here. The bottom line is either: Get survey information or have no information. Accordingly, the use of survey information has a long-standing tradition of complementing more conventional data when necessary. Examples with respect to financial markets include the financial decision-making of households (Lease, Lewellen and Schlarbaum, 1974), the portrayal of views from central bankers (Blinder, 2000), finance academics (Welch, 2000) or financial executives (Brav et al., 2005) and the comparative analysis of individual and institutional investors' views (Shiller and Pound, 1989). ${ }^{7}$ We conclude that questionnaire surveys can provide unique and important information; however, data must be reliable and representative.

In order to realize these goals, a series of intensive interviews with the members of the target group in each country precedes each survey. We develop the questionnaire during the course of these interviews until the first survey takes place in Germany and thereafter keep this version almost unchanged (aside from some slight adjustment to the individual countries). A pretest is conducted in all countries. In this manner, we are quite confident that the items are formulated in such a way as to minimize misunderstanding. Moreover, we get support from three apex organizations of asset management firms, the ones in Germany, Italy and Thailand. In the US, we send out the questionnaire in cooperation with a US university. All this probably signals to the fund managers that knowledgeable "others" also support the survey. Finally, there is hardly any incentive for professionals to make wrong statements. The survey is anonymous, single responses cannot influence the outcome (due to overall sample size) and, finally, there is no reason why fund managers should not be helpful.

Their major constraint is time; higher ranking fund managers may delegate the survey response to junior staff, so it is therefore important for our research that it is not only marginal persons in this business who respond. As regards the fund managers in our sample, Table 2 shows that the average respondent (equal weighting of countries) is about 35 to 42 years old, has almost ten years' professional experience in asset management and has successfully absolved an academic education (about $90 \%$ of respondents). A potentially even more important

\footnotetext{
${ }^{7}$ One may also consider the vast literature based on expectation data which are collected by surveys (overview by MacDonald, 2000).
} 
fact is that about every second respondent has a senior position, ranging from senior asset managers to many chief investment officers or chief executive officers answering the questions. In addition to the figures for each of the five countries, the last column in Table 2 gives figures for pooled sample.

With regard to the representation of various fields in fund management (see Table 2), the sample comprises - with larger differences between countries-managers of mutual and pension funds in almost equal proportions. Similarly, equity and bonds fund managers are both well represented. Overall, the total sample size of 692 fund managers ensures that there is enough variety and room for disaggregated analyses.

As far as the representation of firms is concerned, Table 3 shows that about 204 asset management firms participate in the five countries. The response rate differs between countries and is highest in countries where we receive support from the apex organizations. The highest absolute number of 74, however, comes from the US, where we approach-in light of our limited resources - only the largest 250 firms. In order to test representativeness further, we order participating firms - as far as we can identify responses-according to their assets under management, then compare the distribution of our sample with that of the market. ${ }^{8}$ There are no significant differences in any country. Moreover, we find positive correlations between the number of responses per firm with firm size.

Finally, there may be concerns with regard to the representativeness of technicians versus others in our sample. First, there may be a survivorship bias in favor of or against users of technical analysis. Technicians would be overrepresented if technical trading strategies were comparatively successful, thus driving out other fund managers who do not rely on them. However, if the reverse were true, i.e. with technical trading strategies being less successful, then technicians would be driven out of the market. It seems difficult to make any ex ante judgment on such a possible distortion, but one can see ex post whether the one or the other group is more successful in terms of career success; we do not find any evidence in either direction (in the later Subsection 5.2 on personal characteristics), which cautiously indicates usefulness of our sample.

Another, second, concern with regard to the representativeness of technicians stems from possible time-dependent influences. During 2003/04, when the survey was conducted, stocks were valued relatively low but were increasing in value over time. For example, the

\footnotetext{
${ }^{8}$ Despite the opportunity to keep anonymity almost all firms have signalled their participation although the fund managers themselves always stayed anonymous.
} 
EuroSTOXX50 increased from about 2,300 to 2,800 during the survey period of about 15 months. So did this particular time-period favor, or rather disadvantage, the use of technical analysis thus leading to distorted information? We analyze possible relations between the exact time of the response and the use of technical analysis but cannot find any stable relation, cautiously indicating that the sample will hardly be spoiled by such an effect.

Overall, the survey data are expected to provide reliable and largely representative information towards discovering the importance of technical analysis, a point which is analyzed in the following section.

\section{The importance of technical analysis}

This section addresses the basic question regarding the role of technical analysis in fund management: Is it important enough to deserve further attention? The survey provides a clear answer, as in each country of our sample the vast majority of fund managers use technical analysis. At forecasting horizons of up to some weeks-indicating tactical asset allocation decisions - technical analysis is seen as even more important than fundamental analysis.

There is not much systematic information on the importance of technical analysis for fund mangers that could guide our ex ante expectations. So we take findings from foreign exchange as a first rough benchmark. Starting with Taylor and Allen (1992), three stylized facts, reported here in an abbreviated form, have emerged (Menkhoff and Taylor, 2007): First, almost all professionals use technical analysis to some degree, second, most professionals use some combination of technical and fundamental analysis, and, third, technical analysis becomes relatively more important for shorter-term horizons.

In accordance with earlier surveys, we ask fund managers how much importance they attach to either fundamentals or technical analysis or (order) flows. As can be seen from Table $\underline{4}$, there is a vast majority of $87 \%$ that use technical analysis at all; the figure is identical if we calculate it as unweighted average of the five country means. If we request a higher hurdle to accept the use as being really important for their decision making, we find that $77 \%$ still give it a weight of $10 \%$ and more. Of course, with an even higher hurdle, the weights go down, as shown in Table 4 for minimum levels of $20 \%$ and $30 \%$ importance. However, it seems noteworthy that there are about $20 \%$ of fund managers who prefer the use of technical analysis 
compared to fundamentals and flows; the figure is $18 \%$ if we calculate an average of country means. ${ }^{9}$

Despite this importance of technical analysis—also indicated by an average importance of $23 \%$ - it is fundamentals that, on average, clearly dominate at $67 \%$, whereas flows (order flow, observed transactions) lag behind at $10 \%$. This pattern is quite robust across countries, despite a few noticeable differences. The use of technical analysis in fund management is highest in the three European countries and lowest in the US. This difference is statistically highly significant, for both fundamental and flow analysis (see last column in Table 4). The full distribution of answers is shown in Figure 1: The plane below the lines represents graphically the weight given to technical analysis in each country, whereas the plane above the lines indicates the weight given to fundamentals and flows together. Interestingly, the US line intersects the four other lines, demonstrating that it has the most extreme attitudes towards technical analysis, placing either no importance or-possibly less expected—very high importance on it.

Such minor differences disappear, however, when we turn to the third stylized fact, i.e., the relationship of technical analysis with shorter-term horizon. The respective question directly asks fund managers for their typical forecasting horizon when applying these kinds of information (for some trading rules horizons may differ from the "typical" horizon, see Schulmeister, 2009). Figure 2 gives the distribution of answers. When looking, for example, at the use of technical analysis by US fund managers, the most often applied horizon for this instrument is weeks or a few months, whereas fundamentals are used at longer horizons, such as many months, and flows are preferably applied at very short horizons, such as days. This same pattern holds for fund managers from the four other countries as well. Thus, results are consistent across countries and in line with findings for foreign exchange (Menkhoff and Taylor, 2007).

In summary, $87 \%$ of fund managers use technical analysis to some extent, with a range between the five countries of $68 \%$ to $94 \%$. Technical analysis is consistently of particular importance at a shorter-term (forecasting) horizon, such as weeks. At this horizon, technical analysis is clearly more important than fundamentals or flows.

\footnotetext{
${ }^{9}$ The importance of technical analysis is consistent with the finding that our fund managers rely to a large degree on strategies with a technical appeal, i.e. momentum and tentatively also contrarian trading strategies. These strategies together receive a share of between 30 and $40 \%$ among five alternatives of trading strategies, although their combined share is lower than that of fundamentalist strate-
} 


\section{Correlates of technical analysis}

The following five subsections provide evidence on fund managers' use of technical analysis from five areas: Psychological influences, their personal, behavioral and business characteristics and fund managers' beliefs. In each section, we correlate fund managers' responses, such as their education, with the degree to which these fund managers use technical analysis. This provides detailed information about relations, which seems appropriate for an explorative study and also helps to link some findings to earlier studies. Results are given country by country, showing which relations are of a more general kind. Evidence is interpreted from the viewpoint of the three positions formulated.

\subsection{Psychological influences}

The investigation of a possible relation between using technical analysis and believing in important psychological influences on financial markets has two motivations. First, there is the literature which has inspired our position 3, formulated in Section 2 above. Heterogeneous information processing can have different kinds of motivation, as we have argued, but one line of argument is very straightforward: If there is a "social dynamic" (Shiller, 1984) with relevance for price dynamics, then conventional capital market models will miss an important price determinant. At the same time, technical analysis may, due to its approach, be able to capture such dynamics. A second motivation to examine the nexus between technical analysis and psychological influences is available evidence from foreign exchange. Several studies in this field consistently report this relation, so that it is regarded as a stylized fact (Menkhoff and Taylor, 2007). Does this relation also hold for fund managers in several countries?

Figure 3 presents the relation of interest by denoting the intensity of the use of technical analysis to a survey item capturing psychological influences. Regarding the latter, fund managers were asked to respond to the following statement with their individual degree of agreement or disagreement: "People are not machines; thus, security prices are clearly more determined by psychological influences than by fundamentals" (emphasis added). Interestingly, answers on average rather affirm than reject the statement (exact figures in later Table 8). Our focus, however, is on the relation between technical analysis and psychological influences. Figure 3 gives the frequency distribution of all responding fund managers regarding these two 
dimensions: A positive relation between the use of technical analysis (given in seven categories on the left axis) and a perceived dominance of psychological influences on prices (given in six categories on the bottom axis) is easily visible in our sample. We will show later by statistical analyses that this relation also holds in each country (Subsection 6.5) and that it survives the consideration of any control variable (Section 7).

This evidence is consistent with position 3 and provides motivation to further examine related beliefs of fund managers in more detail (see Subsection 6.5). Next, however, we examine personal characteristics.

\subsection{Personal characteristics}

This subsection contains a test of position 1, stating that users of technical analysis show limited rationality or are characterized by other indicators of inferiority. We do not find any evidence in support of this position, either for any characteristic or for any country in the sample.

It is at this point that we introduce the method that we apply as it is used in the same way in the following subsections. First, we define information that might help us to test the position, i.e., here to learn about the rationality of fund managers. It is obvious that we do not have the direct knowledge about fund managers' rationality that might be inferred by a psychological test. However, survey information can be informative about personal characteristics that are revealing with respect to rationality. We define four characteristics in this respect.

First, the age of fund managers indicates their accumulation of professional knowledge. Assuming that good fund managers will be kept in the market and bad ones will be driven out of it, older fund managers tend to be superior to younger colleagues. As a consequence of the selection process, older fund managers should behave in a relatively rational way and thus contribute better towards efficient markets. Second, one might prefer to reduce the information contained in the age-variable to the professional experience in asset management. More experienced fund managers are expected - in analogy to the above discussion- to be superior to less experienced ones. Third, one can reasonably expect that education helps to improve decision-making in fund management. Finally, we argue that fund managers in higher positions have proved their proficiency.

For these four characteristics, which supply information about the rationality and superiority of fund managers, we compile survey information in an ordinal form. For example, age 
is measured in six categories. ${ }^{10}$ Thus we choose a non-parametric rank correlation to infer whether there is a significant relation between these characteristics and the degree to which technical analysis is used. Table 5 presents the exact formulation of the four items in the questionnaire and the coefficients of correlation. We show the coefficients for the five countries separately in order to examine robustness across countries; in addition we show coefficients for the pooled sample.

Obviously, there is only one out of the possible 20 country coefficients statistically significant at a level of at least 5\%, i.e., better educated Thai fund managers use technical analysis more. To control for some interdependencies between the four variables we also put them into one ordered probit regression per country where the use of technical analysis is measured in categories (not shown here). The formerly significant education variable in Thailand becomes insignificant, but position is positively correlated with technical analysis in the US and Thailand, indicating that managers in better positions in these countries use this instrument more. As this result seems to depend on the exact specification, we do not put too much emphasis on it but note that evidence-if anything — is rather against expectations derived from position 1. In addition, the experience variable becomes significant in the pooled sample (column "ALL"). However, this result is basically driven by the coincidence of high experience and comparatively little use of technical analysis in the US. ${ }^{11}$

We conclude that the use of technical analysis is unrelated to personal characteristics, a finding that is in accordance with the literature in foreign exchange and that does not provide evidence in favor of position 1.

\subsection{Overconfidence}

Studies examining behavioral distortions have shown some surprising results, in particular that professionals sometimes behave in an inferior way to laymen (e.g. Haigh and List, 2005). This motivates the testing of another dimension of "inferiority" in addition to the more conventional indicators used in Subsection 6.2 above. We advance the test of position 1 by linking indications of overconfidence to the use of technical analysis. Again, there is no robust relation.

\footnotetext{
${ }^{10}$ The reason for asking fund managers to give answers in categories is to increase the perception of anonymity because a certain age may already be enough to identify the respondent in one's firm.

${ }^{11}$ If we rerun this analysis by normalizing the level of technical analysis across countries, i.e. focusing on within country relations, the significance of the coefficient disappears completely.
} 
Overconfidence is a general characteristic of investors, laymen and professionals alike. In the past, overconfidence has mainly been seen as a distortion in decision-making that will cause reduced investment performance (Barber and Odean, 2000). Recent research, however, questions this interpretation. Oberlechner and Osler (2008) find that overconfidence does not reduce performance of foreign exchange traders and Ko and Huang (2007) show that overconfidence could lead to high information acquisition and thus improved market efficiency. Thus, in case there is any relation between overconfidence and the use of technical analysis, it may be worthwhile to dig deeper; in the first instance, however, the question arises whether the potential relation of interest exists at all.

When analyzing overconfidence, Glaser and Weber (2007) find that different measures of overconfidence may lead to inconclusive results. Accordingly, we include the three dimensions of overconfidence as they have been found in earlier studies. The first dimension of overconfidence is unrealistically positive self-evaluation ("better than average"), the second is illusion of control and the third is miscalibration. We use basically the same items as Menkhoff, Schmidt and Brozynski (2006) in our survey to capture these dimensions and find, indeed, internationally uniform results. Table 6, Panel A shows for the first dimensionunrealistically positive self-evaluation - that fund managers typically assess their own achievements above average, as the mean values are between 2.7 for the US and 3.2 for Thailand, compared to a "market-neutral" self-assessment of 4 on a scale from 1 to 7 . Moreover, they rather claim not to be surprised by news and they underestimate return variance in their forecasts. Thus, they are overconfident in each dimension, which we mention here to demonstrate that our sample is not different from others.

These three items - indicating overconfidence - are then related to the use of technical analysis. Table 6, Panel B presents the respective coefficients of rank correlations. One can directly see that there is hardly any significant coefficient. Only Thai fund managers fulfill expectations of position 1 to some degree (and Germans in one category to a marginal extent): Those who are worse in calibration use technical analysis more intensively. Results are also unconvincing for the pooled sample. Here, item 1 becomes significant, indicating that technicians are less overconfident with respect to their achievements in asset management; but this result is neither robust nor consistent. ${ }^{12}$

\footnotetext{
${ }^{12}$ When we normalize country levels of the use of technical analysis, the coefficient on item 1 becomes borderline significant, whereas the coefficient on item 3 turns highly significant, showing a positive relation between overconfidence and the use of technical analysis (results not shown here).
} 
As an intermediate summary, the test of position 1 conducted in Subsection 6.2 (personal characteristics) and Subsection 6.3 (overconfidence) does not receive support: The use of technical analysis appears to be unrelated to these indicators of personal or behavioral "deficiencies". Thus, we turn to position 2 , arguing that fund managers using technical analysis respond to their-institutionally caused-incentives.

\subsection{Business characteristics}

Institutional incentives clearly influence decision-making in financial markets and we show that they are related to the degree at which technical analysis is used. This provides some support for position 2.

We focus on the findings that larger financial institutions employ "better" analysts (Hong, Kubik and Solomon, 2001; Clement and Tse, 2005) and that mutual fund managers are exposed to fewer agency problems than pension fund managers, which may avoid costs that draw on performance (Lakonishok, Shleifer and Vishny, 1992). These business characteristics are proxied with the help of four indicators. First, larger firms, here asset management companies with more assets under management, have better abilities to either create their own research or to pay for qualified research from other sources. Assuming that fundamental research is tentatively more expensive than technical analysis, this translates into larger firms putting more emphasis on fundamentals and less on technical analysis. Another item is the time fund managers can spend on data procurement and research. Again, we argue that more time for research should allow more focusing on fundamental analysis.

Descriptive statistics for these items can be seen in Table 7, Panel A. Thai asset management firms are relatively small, with a mean volume of about $10 \mathrm{bn}$. USD, and Swiss respondents' firms are the largest in the sample, with a mean size of more than $50 \mathrm{bn}$. USD. ${ }^{13}$ In any case, there is a lot of variation within each country and enough overlap in firm size between countries. In contrast to this heterogeneity, mean values for average time spent on research are internationally similar (and range between 18.3 hours per week in Switzerland and Thailand and 21.7 hours in Italy.)

Regarding the second kind of business characteristics mentioned above-pension vs. mutual funds-we have asked fund managers about their major responsibility. Following La- 
konishok, Shleifer and Vishny (1992), we argue that the agency problems in the pension fund business do not support the reliance on fundamental analysis. Finally, we test whether bond managers may have a different preference concerning the categories of analysis-there is no ex ante expectation on this item, it serves mainly as a control variable. Descriptive information on these items was provided in Table 2 above, showing that pension and mutual fund managers are roughly balanced in the sample, whereas equity fund managers outnumber bond fund managers by about two to one on average.

In contrast to the two previous subsections, Table 7, Panel B does indeed reveal consistent significant coefficients of correlation. The firms' size variable has the expected and statistically significant sign in Germany, the coefficients in Switzerland and Thailand are borderline significant (significant at the 10\% level) and the remaining countries—US and Italy-have the same negative sign as the three other countries. Taken together, and as evident in the full sample, these results provide evidence that fund managers in smaller asset management firms use technical analysis more.

In order to further examine this relation, $\underline{\text { Panel } \mathrm{C}}$ in Table 7 provides the mean importance of technical analysis in small versus large firms for all five countries. Obviously, each country fulfills the expectation that technical analysis is used more in small than in large firms. In the US, for example, values are $19 \%$ to $14 \%$, so that managers in small firms use technical analysis by $37 \%$ more than colleagues from large firms. Despite this clear difference, behavior is so heterogeneous in this limited sample that the difference is not statistically significant. This applies in a similar way to most other countries. Therefore, if we pool countries, we find a difference of $25 \%$, which is highly significant.

The result for the variable "time for research" tentatively supports the firm size variable. The coefficients of correlation in Panel A show that fund managers from the US and Germany with less time rely significantly more on technical analysis, which also dominates the pooled sample. The other countries—with smaller sample sizes—do not reveal any significant coefficient.

Turning to the third item in Table 7-pension vs. mutual funds-there is no obvious relationship within countries; the significant coefficient on the full sample is mainly driven by country heterogeneity. ${ }^{14}$ For the last variable we find that bond managers in the US and Ger-

\footnotetext{
${ }^{13}$ We do not distinguish between US dollar and euro as the exchange rate between these currencies during the survey period was close to one.

${ }^{14}$ Consequently, it becomes borderline significant if we normalize the use of technical analysis.
} 
many rely more on technical analysis than equity managers, but the three other countries have the opposite coefficient sign, being borderline significant for Italy and close to significance for Switzerland. We therefore hesitate to put any general interpretation on the type of fund managed and the major investment segment.

In summary, the examination of business characteristics provides some tentative evidence that technical analysis is used both by fund managers from smaller firms and those who have less time for research. This suggests support for position 2, interpreting the use of technical analysis as a response to incentives, here as a second best solution to address constraints in information-processing capacity. We now turn to tests of position 3.

\subsection{Beliefs about fund managers' behavior}

If one allows for the possibility that markets do not always reflect the price of an undisputed equilibrium model but that there may be heterogeneity in information processing, this provides a strong rationale for trying to understand such processes. Technical analysis may be seen as an instrument for understanding price determinants that cannot be derived from a generally accepted fundamental model.

We examine in the following whether four statements indicating interesting beliefs are related to users of technical analysis. First, a complex which is often mentioned as a shortcoming of real-world financial markets is the phenomenon of herding. We thus ask whether herding is observable and, second, whether herding is beneficial in the sense that it benefits the fund manager's career. As our next step in this sequence, we ask, thirdly, whether herding is practiced by the respondent in the sense that he generally follows the trend. Finally, we here report statistics - comparable in form to the other items - on the relative importance of psychological influences versus fundamentals (see Subsection 6.1). If the use of technical analysis were indeed rooted in such beliefs then coefficients of relation should be negativeaccording to our encodings.

The responses to these four items are presented in Table 8, Panel A. Obviously, fund managers agree strongly on the notion of herding. However, small majorities reject the idea that herding would benefit the career, the idea that they themselves follow the trend and that psychological influences dominate fundamentals. With the exception of item 1, i.e., the observation of herding among fund managers, deviation around the mean is considerable, so that opinions among responding fund managers are effectively inhomogeneous. 
Table 8, Panel B presents-following our standard procedure-coefficients of rank correlation of the four belief items with the use of technical analysis. The many significant coefficients at the country level-and even more the pooled results—signal that these beliefs may be helpful in understanding the use of technical analysis. Starting with the first item, technicians are only slightly more persuaded than the average fund manager that herding is observable. Views of technicians become somewhat more pronounced when it comes to the benefits of herding. Interestingly, support for a herding variable is strongest when we ask about the managers' own behavior (item 3): In four countries, fund managers do follow the trend more strongly when they use technical analysis more. This sequence of three herding items indicates that following the trend is the variable that distinguishes technicians from the others. Interestingly, the view that herding is observable amongst professional asset managers is not a clear characteristic of the users of technical analysis-implying that fundamentalists tend to share this view. However, fundamentalists seem to draw a different conclusion from this observation. A fundamentalist position in the presence of herding will tend to be stabilizing, whereas technical analysis can be both, stabilizing or destabilizing. The destabilizing part does not need any explanation but technical analysis can also be stabilizing, for example when trends towards the fundamental value are enforced or when turning points towards the end of bubble periods are recognized in advance. Finally, the statement of the great importance of psychological influence on prices — which we had presented in Figure 3 above-is shared by proponents of technical analysis to a statistically significant degree in all countries and matches the observation of trend following among fund managers.

In summary, there is clear evidence in favor of position 3: The users of technical analysis seem to have different views about financial markets, as they tentatively follow trends in their decision-making and as they believe in a more important role of psychological influences on pricing, consistent with their observation of herding in the market.

\section{Multivariate correlates of technical analysis}

In this section, we aggregate the information gained in Section 6 into multivariate regressions. This allows us to assess the relative importance of relevant correlates as well as their robustness when considering further possible determinants.

The multivariate regressions start with a specification considering only those variables that were unanimously statistically significant in Section 6, i.e. two items from business characteristics (Table 7)—firm size and time for research—and the four items from beliefs about 
asset managers' behavior (Table 8)—herding amongst professional asset managers, herding benefits career, trend following and psychological influences. We also include country dummies allowing for country-specific levels in the use of technical analysis (see Table 4). The result shows that most coefficients are statistically significant in the joint estimation with the same sign as in the bivariate correlations, see column (1) of Table 9. Moreover, the size of coefficients may be cautiously interpreted, as variables are similarly coded; only the item "time for research" has roughly to be inflated by a factor of three. The coefficient sizes indicate that belief variables are clearly most important in explaining the use of technical analysis. This mainly confirms position 3 and also position 2 , although more robustness tests seem to be necessary.

In a subsequent step, we reduce the number of variables by excluding the two herding items which are insignificant in specification (1) because they are highly correlated with the further items about fund managers' beliefs. The resulting specification (2) does not provide a new insight. Thus, we add the four personal characteristics, i.e. age, experience, education and position in specification (3). Again, the earlier results are robust. Finally, we include the two most important indicators of overconfidence according to Subsection 6.3. These variables show the same signs as before; i.e., they indicate a contradictory influence of overconfidence on the use of technical analysis. Thus, position 1 does not receive support. We note that country dummies are almost unchanged through all specifications, i.e., the reason why they are not listed in Table 9. In non-reported regressions we experiment with further specifications, considering either more or less or different sets of variables, but our main findings are unaffected by these changes. This includes specifications with "normalized" levels of the use of technical analysis.

\section{Conclusions}

From an academic point of view, the use of technical analysis is mostly looked upon very skeptically, as it seems difficult to imagine why backward-looking behavior should help investors to predict future returns. This skepticism is well expressed in Fama's (1970) statement that financial markets are weakly efficient, implying that the analysis of past prices cannot provide profitable forecasts. In contrast to this established view in the finance profession, practitioners seem to rely on technical analysis. This paper presents survey evidence from fund managers in five countries in order to better understand this phenomenon: How impor- 
tant is technical analysis among professionals nowadays, how do they use it and why do they use it?

We present empirically substantiated answers to all the three questions just raised; findings hold for each of the five countries examined: First, technical analysis is important, as the vast majority of fund managers use it to some extent. Second, technical analysis is used in preference as a complement to fundamental analysis. As such, it is used at shorter-term forecasting horizons. Up to horizons of weeks, it is more important than fundamental analysis in all countries. Third, our evidence strongly supports what we have called position 3; that is the view of heterogeneous information-processing in financial markets. Users of technical analysis share the view that psychological influences are an important pricing determinant in financial markets, they tend to believe that herding is beneficial and thus rely on trend-following behavior. We also find some support for position 2, indicating that high information costs of fundamental analysis may contribute to the use of technical analysis. There is no consistent evidence for position 1 that the users of technical analysis may be in some way inferior to other fund managers - they are equally well experienced, educated, successful and overconfident in decision-making.

Overall, does this suggest that financial markets are inefficient? To be sure, this research does not provide an answer to this question. We would prefer to take Fama's (1970) advice seriously, not to regard market efficiency too literally. There is obviously severe disagreement about the most appropriate understanding of financial markets: Some fund managers seem to believe more in the power of conventional fundamentals to explain returns, whereas others see an important role for psychological influences. Finding consistent behavior among these professionals may provide some reassurance: Each group will consider its own reactions as rational. 


\section{References}

Arnswald, T., 2001. Investment behaviour of German equity fund managers: An exploratory analysis of survey data. Deutsche Bundesbank Discussion Paper 08/01.

Barber, B.M., Odean, T., 2000. Trading is hazardous to your wealth: Common stock investment performance of individual investors. Journal of Finance 55, 773-806.

Blinder, A.S., 2000. Central-bank credibility: Why do we care? How do we build it? American Economic Review 90, 1421-1431.

Blume, L., Easley, D., O'Hara, M., 1994. Market statistics and technical analysis - the role of volume. Journal of Finance 49, 153-183.

Brav, A., Graham, J.R., Harvey, C.R., Michaely, R., 2005. Payout policy in the 21st century. Journal of Financial Economics 77, 483-527.

Brock, W.A., Hommes, C.H., 1998. Heterogeneous beliefs and routes to chaos in a simple asset pricing model. Journal of Economic Dynamics and Control 22, 1235-74.

Brock, W.A., Lakonishok, J., LeBaron, B., 1992. Simple technical trading rules and the stochastic properties of stock returns. Journal of Finance 47, 1731-1764.

Brown, D.P., Jennings, R.H., 1989. On technical analysis. Review of Financial Studies 2, 527551.

Chang, P.H.K., Osler, C.L., 1999. Methodical madness: Technical analysis and the irrationality of exchange-rate forecasts. Economic Journal 109, 636-661.

Cheung, Y.-W., Chinn, M.D., 2001. Currency traders and exchange rate dynamics: A survey of the US market. Journal of International Money and Finance 20, 439-471.

Cheung, Y.-W., Chinn, M.D., Marsh, I.W., 2004. How do UK-based foreign exchange dealers think their market operates? International Journal of Finance and Economics 9, 289-306.

Cheung, Y.-W., Wong, C.Y.-P., 2000. A survey of market practitioners' views on exchange rate dynamics. Journal of International Economics 51, 401-423.

Clement, M.B., Tse, S.Y., 2005. Financial analyst characteristics and herding behavior in forecasting. Journal of Finance 60, 307-341.

De Grauwe, P., Grimaldi, M., 2006. Exchange rate puzzles: A tale of switching attractors. European Economic Review 50, 1-33.

De Long, J.B., Shleifer, A., Summers, L.H., Waldmann, R.J., 1990. Noise trader risk in financial markets. Journal of Political Economy 98, 703-738. 
Davis, E.P., Steil, B., 2001. Institutional Investors. MIT Press: Cambridge.

Fama, E.F., 1970. Efficient capital markets: A review of theory and empirical work. Journal of Finance 25, 383-417.

Frankel, J.A., Froot, K.A., 1990. Chartists, fundamentalists, and trading in the foreign exchange market. American Economic Review 80, 181-85.

Friesen, G.C., Weller, P.A., Dunham, L.M., 2009. Price trends and patterns in technical analysis: A theoretical and empirical examination. Journal of Banking and Finance 33, 1089-1100.

Glaser, M., Weber, M., 2007. Overconfidence and trading volume. Geneva Risk and Insurance Review 32, 1-37.

Griffin, J.M., Ji, S., Martin, J.S., 2003. Momentum investing and business cycle risk: Evidence from pole to pole. Journal of Finance 58, 2515-2547.

Grinblatt, M., Titman, S., Wermers, R., 1995. Momentum investment strategies, portfolio performance, and herding: A study of mutual fund behavior. American Economic Review 85, 1088-1105.

Grossman, S., Stiglitz, J.E., 1980. On the impossibility of informationally efficient markets. American Economic Review 70, 393-408.

Haigh, M.S., List, J.A., 2005. Do professional traders exhibit myopic loss aversion? An experimental analysis. Journal of Finance 60, 523-534.

Harris, R.D.F., Yilmaz, F., 2009. A momentum trading strategy based on the low frequency component of the exchange rate. Journal of Banking and Finance 33, 1575-1585.

Hellwig, M.F., 1982. Rational expectations equilibrium with conditioning on past prices: A mean-variance example. Journal of Economic Theory 26, 279-312.

Hirshleifer, D., 2001. Investor psychology and asset pricing. Journal of Finance 56, 15331597.

Hong, H., Kubik, J.D., Solomon, A., 2000. Security analysts' career concerns and herding of earnings forecasts. Rand Journal of Economics 31, 121-144.

Jegadeesh, N., Titman, S., 2001. Profitability of momentum strategies: An evaluation of alternative explanations. Journal of Finance 56, 699-720.

Kavajecz, K.A., Odders-White, E.R., 2004. Technical analysis and liquidity provision. Review of Financial Studies 17, 1043-1071.

Kliger, D., Kudryavtsev, A., 2008. Reference point formation by market investors. Journal of Banking and Finance 32, 1782-1794. 
Ko, K.J., Huang, Z., 2007. Arrogance can be a virtue: Overconfidence, information acquisition, and market efficiency. Journal of Financial Economics 84, 529-560.

Lakonishok, J., Shleifer, A., Vishny, R.W., 1992. The structure and performance of the money management industry. Brookings Papers on Economic Activity: Microeconomics, 339-391.

Lease, R.C., Lewellen, W.G., Schlarbaum, G.G., 1974. The individual investor: Attributes and attitudes. Journal of Finance 29, 413-433.

Li, X., Miffre, J., Brooks, C., O’Sullivan, N., 2008. Momentum profits and time-varying unsystematic risk. Journal of Banking and Finance 32, 541-558.

Lo, A.W., Mamaysky, H., Wang, J., 2000. Foundations of technical analysis. Journal of Finance 55, 1705-1765.

MacDonald, R., 2000. Expectations formation and risk in three financial markets: Surveying what the surveys say. Journal of Economic Surveys 14, 69-100.

Malkiel, B., 2003. The efficient market hypothesis and its critics. Journal of Economic Perspectives $17,59-82$.

Menkhoff, L., 1998. The noise trading approach - questionnaire evidence from foreign exchange. Journal of International Money and Finance 17, 547-564.

Menkhoff, L., Schmidt, U., Brozynski, T., 2006. The impact of experience on risk taking, overconfidence, and herding of fund managers: Complementary survey evidence. European Economic Review 50, 1753-1766.

Menkhoff, L., Taylor, M.P., 2007. The obstinate passion of foreign exchange professionals: Technical analysis. Journal of Economic Literature 45, 936-972.

Nam, K., Washer, K.M., Chu, Q.C., 2005. Asymmetric return dynamics and technical trading strategies. Journal of Banking and Finance 29, 391-418.

Oberlechner, T., Osler, C.L., 2008. Overconfidence in currency markets. Discussion Paper, Brandeis University.

Osler, C., 2003. Currency orders and exchange-rate dynamics: An explanation for the predictive success of technical analysis. Journal of Finance 58, 1791-1819.

Park, C.-H., Irwin, S.H., 2007. What do we know about the profitability of technical analysis? Journal of Economic Surveys 21, 786-826.

Schulmeister, S., 2007. The interaction between the aggregate behavior of technical trading systems and stock price dynamics. Working Paper, Austrian Institute of Economic Research. 
Schulmeister, S., 2009. Profitability of technical stock trading: Has it moved from daily to intraday data? Review of Financial Economics 18, 190-201.

Shiller, R.J., 1984. Stock prices and social dynamics. Brookings Papers on Economic Activity No.2, 457-498.

Shiller, R.J., 2003. From efficient markets theory to behavioral finance. Journal of Economic Perspectives 17, 83-104.

Shiller, R.J., Pound, J., 1989. Survey evidence on diffusion of interest and information among investors. Journal of Economic Behavior and Organization 12, 47-66.

Taylor, M.P., Allen, H., 1992. The use of technical analysis in the foreign exchange market. Journal of International Money and Finance 11, 304-314.

Treynor, J.L., Ferguson, R., 1985. In defense of technical analysis. Journal of Finance 40, 757775.

Welch, I., 2000. Views of financial economists on the equity premium and on professional controversies. Journal of Business 73, 501-537.

Zhu, Y., Zhou, G., 2009. Technical analysis: An asset allocation perspective on the use of moving averages. Journal of Financial Economics 92, 519-544. 
TABLE 1. Positions taken on the role of technical analysis

\begin{tabular}{|c|c|c|c|}
\hline Characteristics & Position 1 & Position 2 & Position 3 \\
\hline Core characteristic of positions & $\begin{array}{l}\text { Technical analysis as } \\
\text { sign of less than fully } \\
\text { rational behavior }\end{array}$ & $\begin{array}{l}\text { Technical analysis as } \\
\text { rational response to } \\
\text { high information } \\
\text { costs }\end{array}$ & $\begin{array}{l}\text { Technical analysis as } \\
\text { expression of differ- } \\
\text { ent information or } \\
\text { belief sets }\end{array}$ \\
\hline Drivers of heterogeneity & $\begin{array}{l}\text { Different degree of } \\
\text { rationality }\end{array}$ & $\begin{array}{l}\text { Different levels of in- } \\
\text { formation quality }\end{array}$ & $\begin{array}{l}\text { Different sets of in- } \\
\text { formation or beliefs }\end{array}$ \\
\hline Technicians are ... & Less rational & Less well-informed & $\begin{array}{l}\text { Less focused on fun- } \\
\text { damental information }\end{array}$ \\
\hline Rationality of technicians & no & yes & may be \\
\hline Return on technical analysis & $\begin{array}{l}\text { Below the average re- } \\
\text { turn of rational fun- } \\
\text { damental investors }\end{array}$ & $\begin{array}{l}\text { At the market level } \\
\text { after considering in- } \\
\text { formation costs }\end{array}$ & $\begin{array}{l}\text { The same risk- } \\
\text { adjusted return as on } \\
\text { fundamental trading } \\
\text { (after costs) }\end{array}$ \\
\hline $\begin{array}{l}\text { The Efficient Market } \\
\text { Hypothesis is ... }\end{array}$ & Fully appropriate & $\begin{array}{c}\text { Appropriate after cost } \\
\text { adjustment }\end{array}$ & Less appropriate \\
\hline
\end{tabular}

TABLE 2. Information about responding fund managers

\begin{tabular}{|c|c|c|c|c|c|c|}
\hline & US & GER & $\mathrm{CH}$ & ITA & THAI & ALL \\
\hline Average age (in years) & 42.5 & 35.6 & 38.7 & 36.0 & 35.3 & 37.3 \\
\hline $\begin{array}{l}\text { Average professional experience (in } \\
\text { years) }\end{array}$ & 14.0 & 7.4 & 10.6 & 8.8 & 7.0 & 9.2 \\
\hline Academic education (in $\%$ of total) & 81.8 & 86.8 & 86.8 & 93.5 & 96.0 & 88.5 \\
\hline Senior position (in \% of total) ${ }^{\text {(a) }}$ & 84.8 & 68.0 & 92.9 & 83.3 & 61.9 & 74.4 \\
\hline $\begin{array}{l}\text { Mutual fund managers } \\
\text { (vs. pension funds, etc. in \%) }\end{array}$ & 42.0 & 39.1 & 50.0 & 79.0 & 61.5 & 51.2 \\
\hline $\begin{array}{l}\text { Equity fund managers } \\
\text { (vs. bond and money market funds in } \% \text { ) }\end{array}$ & 64.8 & 73.9 & 77.8 & 53.4 & 44.7 & 63.8 \\
\hline
\end{tabular}

TABLE 3. On the representativeness of responses

\begin{tabular}{lccccc}
\hline & US & GER & CH & ITA & THAI \\
Number of individual responses & 149 & 263 & 42 & 112 & 126 \\
Number of responding firms & 74 & 51 & 18 & 32 & 29 \\
Share of responding asset managing firms & $29.6 \%$ & $77.3 \%$ & $29.0 \%$ & $58.2 \%$ & $93.5 \%$ \\
$\mathrm{H}_{0}$ : Structure of responding firms equals & -1.213 & -0.669 & -0.385 & -0.403 & -0.136 \\
structure of the market $^{(\mathrm{a})}$ & $(0.225)$ & $(0.503)$ & $(0.700)$ & $(0.687)$ & $(0.892)$ \\
\hline
\end{tabular}

(a) Firms are characterized by asset under management. For Switzerland, however, the number of mutual funds offered is used as a proxy for the asset management industry. The figures given are the z-value of the Mann-Whitney U-test and the p-value in parenthesis. 


\section{TABLE 4. The relevance of technical analysis}

"How much importance do you attach to the following categories of information?"

Please assign $100 \%$ altogether. If a category does not apply, please assign $0 \%$ to it.

$\%$ Fundamentals (economic and political hard facts)

$\%$ Technical analysis (charts and quantitative indicators)

$\%$ (Order) Flows (observed transactions)

\begin{tabular}{|c|c|c|c|c|c|c|c|}
\hline & US & GER & $\mathrm{CH}$ & ITA & THAI & ALL & $\begin{array}{l}\text { MWU- } \\
\text { Test }^{(\mathrm{a})}\end{array}$ \\
\hline Technical analysis mean & 16.1 & 29.6 & 23.3 & 22.8 & 16.8 & 22.5 & $\begin{array}{c}-8.756^{* * * *} \\
(0.000)\end{array}$ \\
\hline Fundamentals mean & 77.9 & 59.6 & 66.2 & 65.6 & 70.9 & 67.0 & $\begin{array}{c}-7.925 * * * \\
(0.000)\end{array}$ \\
\hline Flows mean & 5.9 & 9.6 & 10.5 & 11.6 & 12.3 & 9.7 & $\begin{array}{c}-5.370 * * * \\
(0.000)\end{array}$ \\
\hline $\mathrm{TA}>0 \%$ & 68.2 & 93.1 & 90.0 & 93.6 & 90.4 & 87.1 & \\
\hline $\mathrm{TA} \geq 10 \%$ & 55.4 & 87.7 & 80.0 & 82.6 & 76.0 & 77.3 & \\
\hline $\mathrm{TA} \geq 20 \%$ & 31.1 & 72.7 & 65.0 & 63.3 & 44.0 & 56.5 & \\
\hline $\mathrm{TA} \geq 30 \%$ & 17.6 & 53.1 & 42.5 & 38.5 & 20.0 & 36.4 & \\
\hline TA preferred & 11.5 & 31.5 & 25.0 & 16.5 & 5.6 & 19.6 & \\
\hline
\end{tabular}

(a) We test the $\mathrm{H}_{0}$ that figures for the US and the group of European countries (GER, CH, ITA) are the same. The figures given are the coefficients of the Mann-Whitney U-Test with p-value in ( ), rejecting the hypotheses.

Stars refer to level of significance: ${ }^{* * *} 1 \%$.

\section{Figure 1. The cumulative distribution of technical analysis' importance ${ }^{(a)}$}

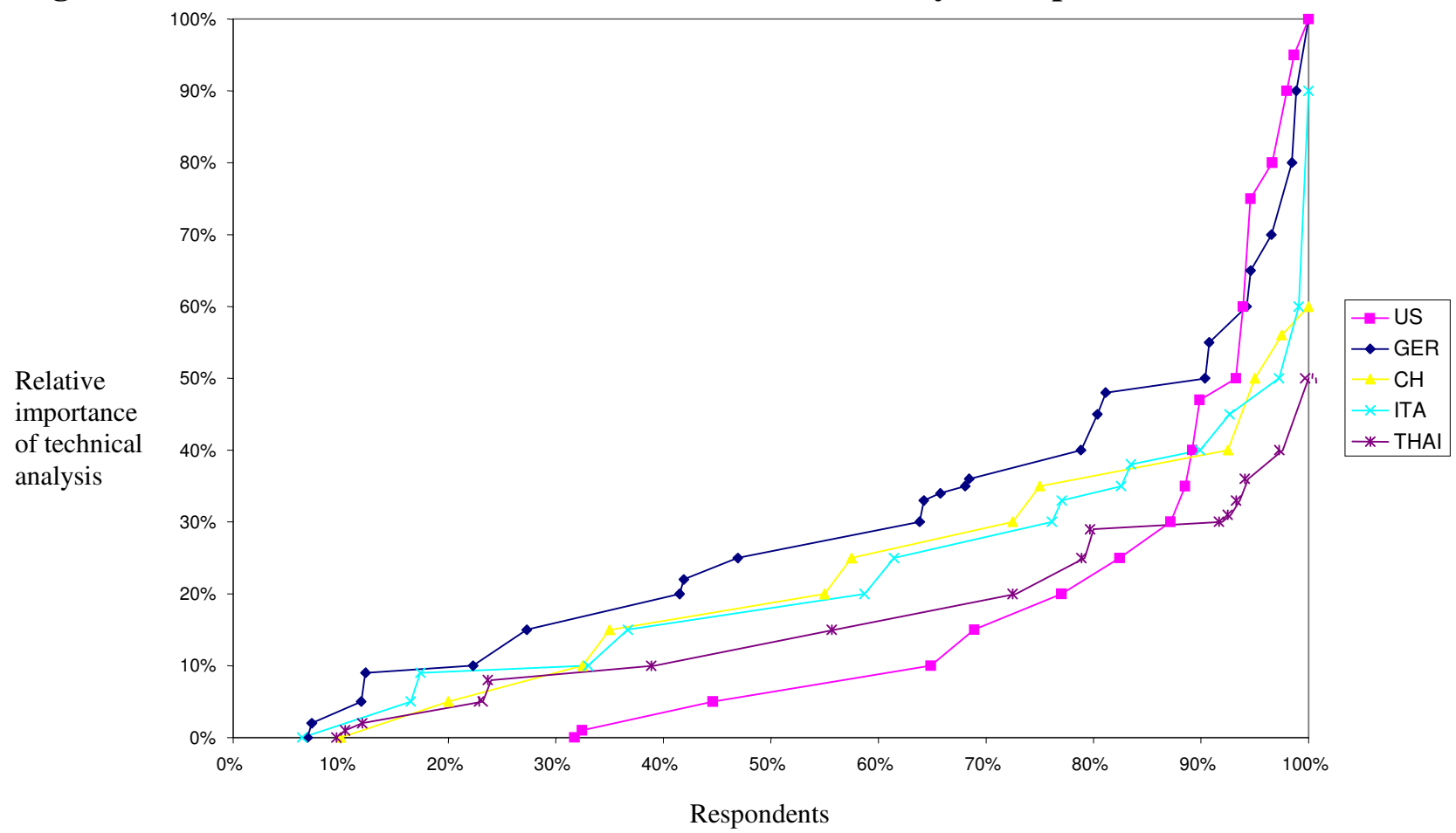

(a) For the measure of technical analysis' importance see Table 4.

For example, this figure shows, that among German fund managers about $7 \%$ of respondents do not use technical analysis at all, a few use it to $2 \%$ or to $5 \%$ or to $9 \%$ (altogether $12.3 \%$ use it to less than $10 \%$ ); then there is a larger group who gives $10 \%$ importance to technical analysis, etc. 


\section{FIGURE 2. The importance of fundamentals, technical analysis and flows at different fore- casting horizons}

Question: "How far in advance reaches your personal forecasting horizon typically when applying the following types of information? Please give one answer each:"

Fundamentals:

Technical analysis:

_ (minutes, hours, days, weeks, months, years)

Flows:

_ (minutes, hours, days, weeks, months, years)

US FUND MANAGERS



GERMAN FUND MANAGERS

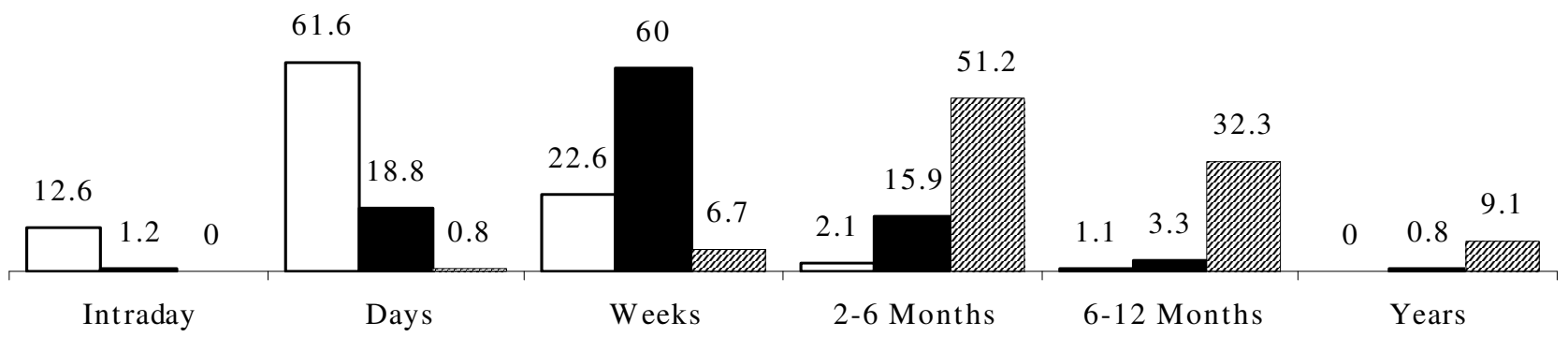

SWISS FUND MANAGERS



ITALIAN FUND MANAGERS

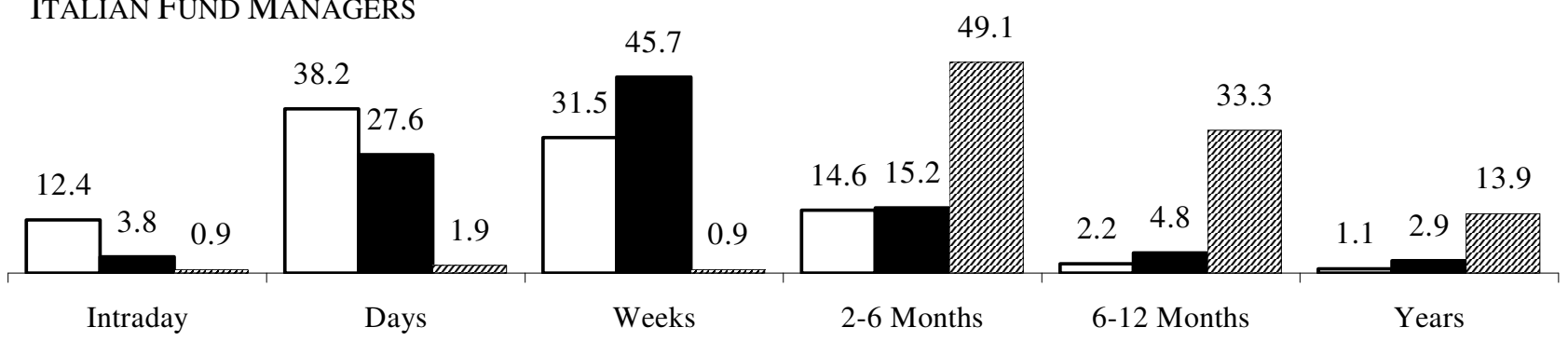

THAI FUND MANAGERS

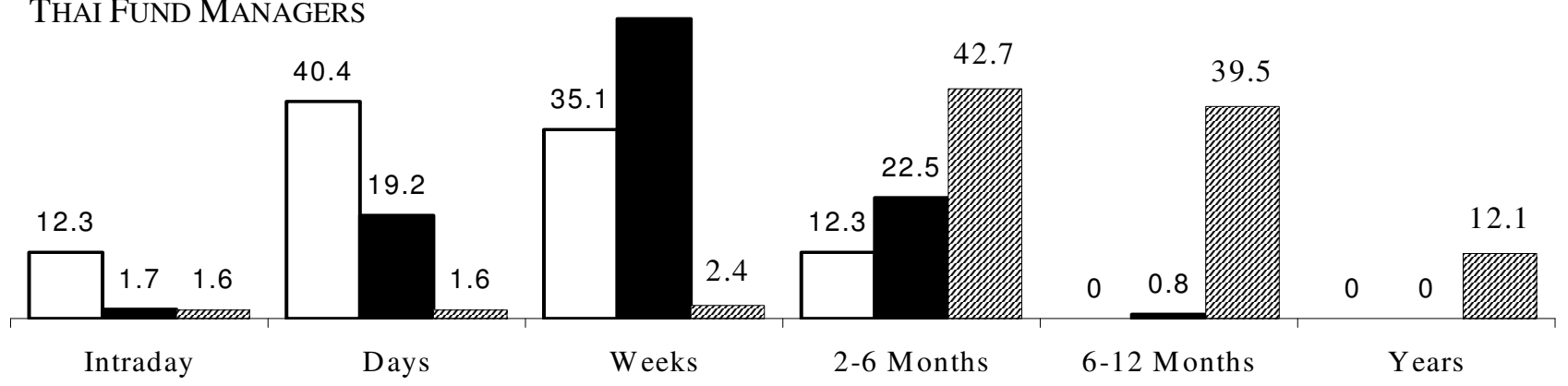


FIGURE 3. Perceived psychological influences and the use of technical analysis

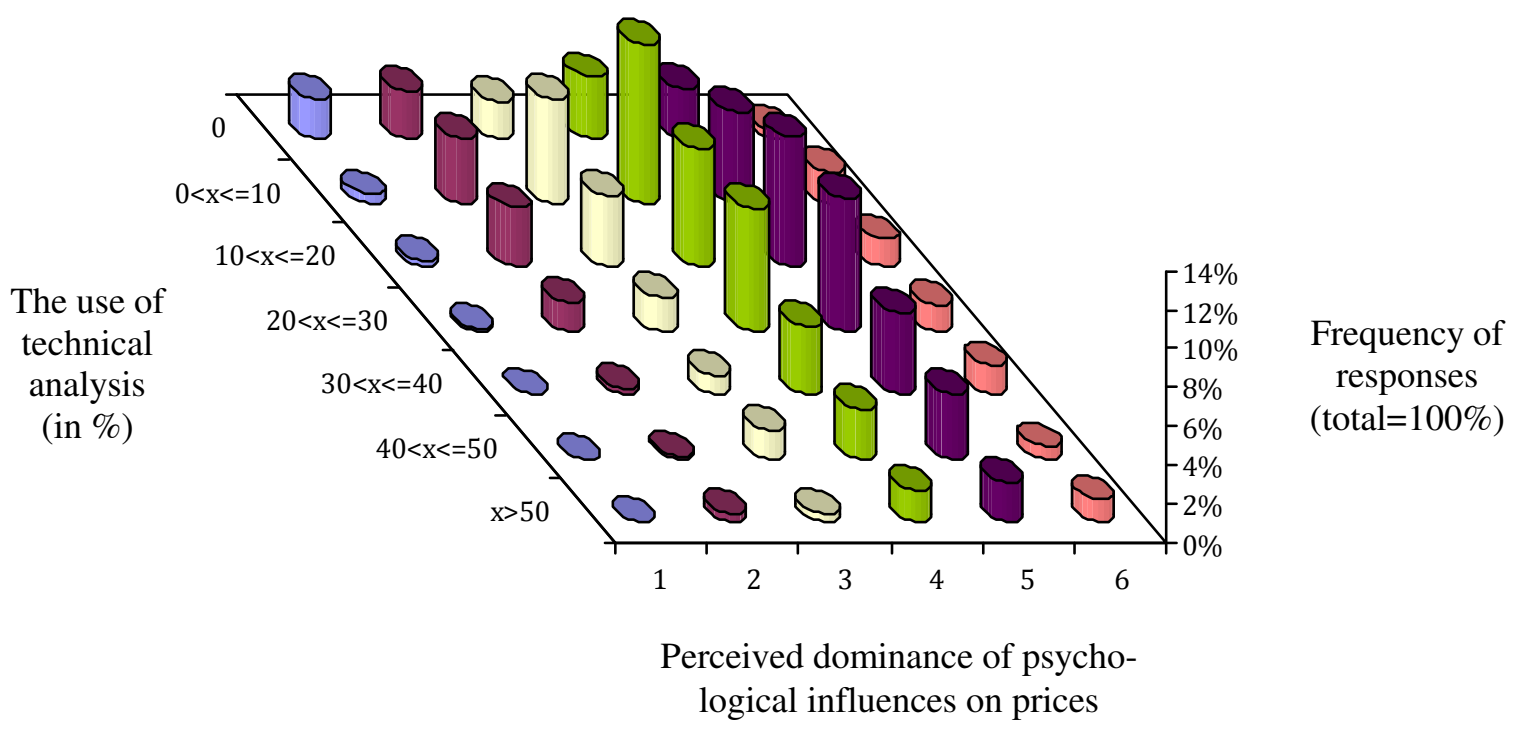

This figure plots responses on the item "use of technical analysis (see Table 4) and on the following item : "People are not machines; thus security prices are clearly more determined by psychological influences than by fundamentals". There are 6 answering categories, ranging from "disagree completely" (coded as 1) to "agree completely" (coded as 6). 


\section{TABLE 5. Personal characteristics and the use of technical analysis}

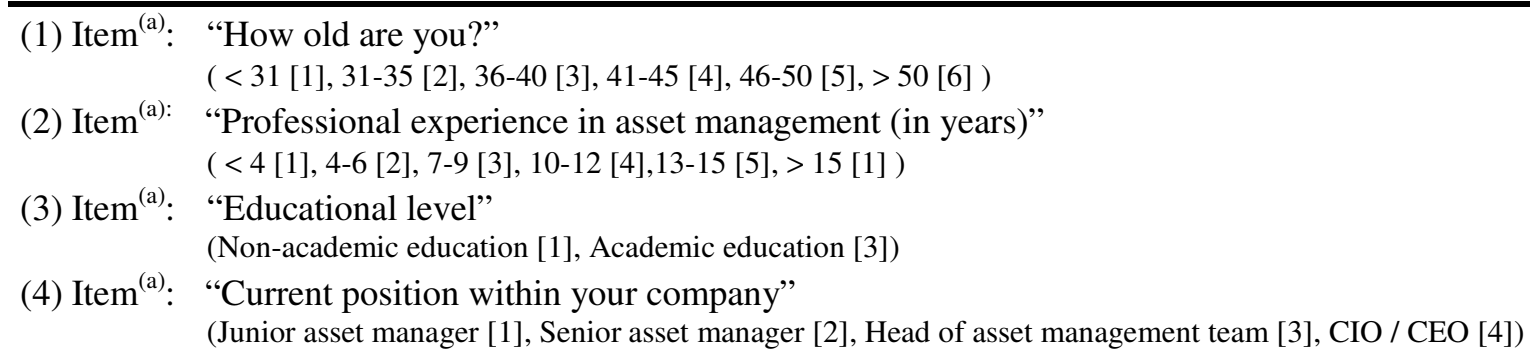

\begin{tabular}{lcccccc}
\hline & \multicolumn{6}{c}{ Coefficients of rank correlation with the use of technical analysis ${ }^{(\mathrm{b})}$} \\
\cline { 2 - 7 } & US & GER & CH & ITA & THAI & ALL \\
(1) Higher age & -0.085 & $0.108^{*}$ & -0.050 & 0.075 & -0.060 & -0.057 \\
& $(0.306)$ & $(0.083)$ & $(0.760)$ & $(0.442)$ & $(0.505)$ & $(0.139)$ \\
(2) More experience & -0.094 & 0.039 & -0.147 & 0.068 & 0.041 & $-0.099^{* *}$ \\
& $(0.259)$ & $(0.534)$ & $(0.370)$ & $(0.494)$ & $(0.647)$ & $(0.011)$ \\
(3) Better education & -0.032 & -0.087 & -0.039 & 0.017 & 0.243 & 0.000 \\
& $(0.707)$ & $(0.167)$ & $(0.821)$ & $(0.862)$ & $(0.006)$ & $(0.991)$ \\
(4) More senior position & 0.057 & 0.059 & -0.094 & -0.056 & 0.034 & 0.000 \\
& $(0.501)$ & $(0.351)$ & $(0.563)$ & $(0.578)$ & $(0.709)$ & $(0.991)$ \\
\hline
\end{tabular}

${ }^{\text {(a) }}$ Response categories and encodings in [ ] in parenthesis.

(b) The figures given are the coefficient of the Spearman rank correlation with p-value in parenthesis.

Stars refer to level of significance: ${ }^{*} 10 \%,{ }^{* *} 5 \%,{ }^{* * *} 1 \%$.

For example, the coefficient of 0.108 for "Germany" and "Higher age" shows that older fund managers in Germany use technical analysis more than younger ones (i.e. that they give relative more importance to technical analysis according to the measure introduced in Table 4). 


\section{TABLE 6. Overconfidence and the use of technical analysis}

(1) Item ${ }^{(a)}$ : "How do you assess your achievement in asset management - compared to other asset managers' achievement in the same investment segment?" (much better [1], ..., much worse [7])

(2) Item ${ }^{(a)}:$ "Most of the published business news does not surprise me at all." (complete approval [1], ..., complete contradiction [6] )

(3) Item $^{(a)}$ : "Please estimate the development of the EuroSTOXX 50 and the Dow Jones within the next month. Please forecast the performance of the respective index with a probability of $90 \%$." (Today's level, expected minimum level, expected maximum level.)

\begin{tabular}{|c|c|c|c|c|c|c|c|}
\hline \multirow[t]{2}{*}{ Panel A } & \multirow{2}{*}{$\begin{array}{l}\text { Response } \\
\text { category } \\
\text { (b) }\end{array}$} & \multicolumn{6}{|c|}{ Descriptive statistics } \\
\hline & & US & GER & $\mathrm{CH}$ & ITA & THAI & ALL \\
\hline $\begin{array}{l}\text { (1) Comparatively } \\
\text { worse achievement }\end{array}$ & $\begin{array}{l}\text { Mean } \\
\mathrm{N}\end{array}$ & $\begin{array}{l}2.7 \\
145\end{array}$ & $\begin{array}{l}3.1 \\
249\end{array}$ & $\begin{array}{l}3.0 \\
39\end{array}$ & $\begin{array}{l}2.9 \\
104\end{array}$ & $\begin{array}{l}3.2 \\
122\end{array}$ & $\begin{array}{l}3.0 \\
659\end{array}$ \\
\hline (2) News does surprise & $\begin{array}{l}\text { Mean } \\
\mathrm{N}\end{array}$ & $\begin{array}{l}3.1 \\
148\end{array}$ & $\begin{array}{l}3.2 \\
262\end{array}$ & $\begin{array}{l}3.1 \\
39\end{array}$ & $\begin{array}{l}3.5 \\
106\end{array}$ & $\begin{array}{l}3.1 \\
126\end{array}$ & $\begin{array}{l}3.2 \\
681\end{array}$ \\
\hline $\begin{array}{l}\text { (3) } 90 \% \text { width of index } \\
\text { forecast: } \\
\text { - EuroSTOXX } 50\end{array}$ & $\begin{array}{c}\text { Mean }^{(c)} \\
\mathrm{N}\end{array}$ & $\begin{array}{c}15.7 \% \\
38\end{array}$ & $\begin{array}{c}23.3 \% \\
213\end{array}$ & $\begin{array}{c}29.6 \% \\
30\end{array}$ & $\begin{array}{l}11.2 \% \\
78\end{array}$ & $\begin{array}{c}15.9 \% \\
119\end{array}$ & $\begin{array}{c}19.3 \% \\
478\end{array}$ \\
\hline - Dow Jones & $\begin{array}{l}\text { Mean } \\
\mathrm{N}\end{array}$ & $\begin{array}{c}28.1 \% \\
74\end{array}$ & $\begin{array}{c}16.8 \% \\
211\end{array}$ & $\begin{array}{c}49.2 \% \\
30\end{array}$ & $\begin{array}{c}9.0 \% \\
76\end{array}$ & $\begin{array}{c}12.9 \% \\
98\end{array}$ & $\begin{array}{c}18.5 \% \\
489\end{array}$ \\
\hline $\begin{array}{l}\text { Share of correct } \\
\text { estimations: } \\
\text { - EuroSTOXX } 50\end{array}$ & $\mathrm{~N}$ & $\begin{array}{c}52.6 \% \\
20\end{array}$ & $\begin{array}{c}92.1 \% \\
199\end{array}$ & $\begin{array}{c}66.7 \% \\
20\end{array}$ & $\begin{array}{c}66.7 \% \\
52\end{array}$ & - & \\
\hline - Dow Jones & $\mathrm{N}$ & $\begin{array}{c}68.1 \% \\
47\end{array}$ & $\begin{array}{c}67.6 \% \\
144\end{array}$ & $\begin{array}{c}50.0 \% \\
15\end{array}$ & $\begin{array}{c}66.7 \% \\
50\end{array}$ & - & \\
\hline
\end{tabular}

\begin{tabular}{lcccccc}
\hline PANEL B & \multicolumn{6}{c}{ Coefficients of rank correlation with the use of technical analysis } \\
\cline { 2 - 7 } & US & GER & CH & ITA & THAI & ALL \\
& 0.102 & 0.091 & -0.177 & -0.005 & 0.089 & $0.114^{* * *}$ \\
(1) Comparatively & $(0.226)$ & $(0.156)$ & $(0.288)$ & $(0.963)$ & $(0.331)$ & $(0.003)$ \\
$\quad$ worse achievement & -0.033 & -0.054 & 0.237 & -0.027 & 0.122 & 0.006 \\
& $(0.695)$ & $(0.383)$ & $(0.153)$ & $(0.785)$ & $(0.176)$ & $(0.867)$ \\
(2) News does surprise & & & & & & \\
& & & & & & \\
(3) 90\% width of index & -0.207 & $-0.124 *$ & 0.156 & 0.064 & $-0.382^{* * *}$ & -0.047 \\
$\quad$ forecast: & $(0.213)$ & $(0.071)$ & $(0.410)$ & $(0.581)$ & $(0.000)$ & $(0.311)$ \\
$\quad$ - EuroSTOXX 50 & -0.009 & -0.077 & 0.053 & 0.055 & $-0.313 * * *$ & -0.037 \\
$\quad$ - Dow Jones & $(0.942)$ & $(0.268)$ & $(0.780)$ & $(0.635)$ & $(0.002)$ & $(0.421)$ \\
\hline
\end{tabular}

(a) Response categories and encodings in [ ] in parenthesis.

(b) $\mathrm{N}$ is the number of responses.

(c) The width is calculated as (expected maximum level- expected minimum level) / average index level.

(d) The figures given are the coefficient of the Spearman rank correlation with p-value in parenthesis.

Stars refer to level of significance: ${ }^{*} 10 \%,{ }^{* *} 5 \%,{ }^{* * *} 1 \%$. 


\section{TABLE 7. Business characteristics and the use of technical analysis}

(1) Item ${ }^{(a)}$ : "Your company's total volume of asset under management (in billion of US dollar or euro)"

( < 5 [1], 5-10 [2], 10-20 [3], 20-50 [4], 50-100 [5], > 100 [6] )

(2) Item $^{(a)}$ : "Average period of data procurement and research" (hours per week)

(3) Item ${ }^{(a): ~ " T y p e ~ o f ~ m a n a g e d ~ f u n d " ~(m u t u a l ~ f u n d ~[1], ~ r e s t r i c t e d ~ / ~ s p e c i a l ~ / ~ p e n s i o n ~ f u n d ~[3]) ~}$

(4) Item ${ }^{(a)}$ : "Major investment segment" (equities [1], bonds and money market [3])

\begin{tabular}{lccccccc}
\hline PANEL A & \multirow{7}{c}{$\begin{array}{c}\text { Response } \\
\text { category }\end{array}$} & \multicolumn{7}{c}{ Descriptive statistics } \\
\cline { 3 - 8 } & & US & GER & CH & ITA & THAI & ALL \\
(1) Firm size & Mean & 3.7 & 4.0 & 4.7 & 3.0 & 2.5 & 3.6 \\
& $\mathrm{~N}$ & 145 & 258 & 40 & 102 & 123 & 668 \\
(2) Time for research & Mean & 21.0 & 20.1 & 18.3 & 21.7 & 18.3 & 20.0 \\
& $\mathrm{~N}$ & 122 & 189 & 30 & 65 & 112 & 518 \\
\hline
\end{tabular}

\begin{tabular}{|c|c|c|c|c|c|c|c|}
\hline \multirow{2}{*}{\multicolumn{2}{|c|}{ PANel B }} & \multicolumn{6}{|c|}{ Coefficients of rank correlation with the use of technical analysis ${ }^{(c)}$} \\
\hline & & US & GER & $\mathrm{CH}$ & ITA & THAI & ALL \\
\hline \multicolumn{2}{|l|}{ (1) Larger firm size } & $\begin{array}{l}-0.051 \\
(0.542)\end{array}$ & $\begin{array}{c}-0.230^{* * *} \\
(0.000)\end{array}$ & $\begin{array}{l}-0.294^{*} \\
(0.073)\end{array}$ & $\begin{array}{l}-0.086 \\
(0.393)\end{array}$ & $\begin{array}{l}-0.150^{*} \\
(0.099)\end{array}$ & $\begin{array}{l}-0.088^{* *} \\
(0.024)\end{array}$ \\
\hline \multicolumn{2}{|c|}{ (2) More time for research } & $\begin{array}{l}-0.211^{* *} \\
(0.019)\end{array}$ & $\begin{array}{l}-0.175^{* *} \\
(0.017)\end{array}$ & $\begin{array}{l}-0.180 \\
(0.359)\end{array}$ & $\begin{array}{c}0.106 \\
(0.402)\end{array}$ & $\begin{array}{l}-0.100 \\
(0.294)\end{array}$ & $\begin{array}{c}-0.121^{* * *} \\
(0.006)\end{array}$ \\
\hline \multicolumn{2}{|c|}{ (3) Pension fund (vs. mutual) } & $\begin{array}{c}0.116 \\
(0.251) \\
100\end{array}$ & $\begin{array}{c}0.113 \\
(0.108) \\
204\end{array}$ & $\begin{array}{c}0.255 \\
(0.182) \\
29\end{array}$ & $\begin{array}{c}-0.085 \\
(0.402) \\
99\end{array}$ & $\begin{array}{c}0.129 \\
(0.308) \\
64\end{array}$ & $\begin{array}{c}0.107^{* *} \\
(0.017) \\
496\end{array}$ \\
\hline \multicolumn{2}{|l|}{$\begin{array}{l}\text { (4) Bonds investment } \\
\text { (vs. equities) }\end{array}$} & $\begin{array}{c}0.221^{* *} \\
(0.013) \\
124\end{array}$ & $\begin{array}{c}0.125^{*} \\
(0.065) \\
220\end{array}$ & $\begin{array}{c}-0.307 \\
(0.119) \\
27\end{array}$ & $\begin{array}{c}-0.199^{*} \\
(0.093) \\
72\end{array}$ & $\begin{array}{c}-0.107 \\
(0.285) \\
102\end{array}$ & $\begin{array}{c}-0.008 \\
(0.851) \\
545\end{array}$ \\
\hline \multirow[t]{2}{*}{ Panel C } & \multirow{2}{*}{$\begin{array}{l}\text { Response } \\
\text { category } \\
\text { (b) }\end{array}$} & \multicolumn{6}{|c|}{ Descriptive statistics } \\
\hline & & US & GER & $\mathrm{CH}$ & ITA & THAI & ALL \\
\hline $\begin{array}{l}\text { Technical analysis in } \\
\text { small firms }\end{array}$ & $\begin{array}{c}\text { Mean in } \% \\
\mathrm{~N}\end{array}$ & $\begin{array}{c}19.2 \\
68\end{array}$ & $\begin{array}{c}35.3 \\
108\end{array}$ & $\begin{array}{c}28.6 \\
10\end{array}$ & $\begin{array}{c}23.4 \\
61\end{array}$ & $\begin{array}{c}18.4 \\
63\end{array}$ & $\begin{array}{l}25.8 \\
310\end{array}$ \\
\hline $\begin{array}{l}\text { Technical analysis in } \\
\text { large firms }\end{array}$ & $\begin{array}{c}\text { Mean in } \% \\
\mathrm{~N}\end{array}$ & $\begin{array}{c}14.0 \\
76\end{array}$ & $\begin{array}{l}25.8 \\
147\end{array}$ & $\begin{array}{c}20.2 \\
28\end{array}$ & $\begin{array}{c}21.8 \\
39\end{array}$ & $\begin{array}{c}15.4 \\
59\end{array}$ & $\begin{array}{l}20.6 \\
349\end{array}$ \\
\hline $\begin{array}{l}\text { Relative use in small } \\
\text { firms }\end{array}$ & & $37.1 \%$ & $36.8 \%$ & $41.6 \%$ & $7.3 \%$ & $19.5 \%$ & $25.2 \%$ \\
\hline $\begin{array}{l}\text { Difference signifi- } \\
\text { cant }^{(\mathrm{e})}\end{array}$ & & $\begin{array}{l}-0.838 \\
(0.402)\end{array}$ & $\begin{array}{l}-4.203^{* * *} \\
(0.000)\end{array}$ & $\begin{array}{l}-1.356 \\
(0.175)\end{array}$ & $\begin{array}{l}-0.532 \\
(0.595)\end{array}$ & $\begin{array}{l}-1.186 \\
(0.235)\end{array}$ & $\begin{array}{c}-3.267^{\text {*** }} \\
(0.001)\end{array}$ \\
\hline
\end{tabular}

${ }^{\text {(a) }}$ Response categories and encodings in [ ] in parenthesis.

(b) $\mathrm{N}$ is the number of responses.

(c) The figures given are the coefficient of the Spearman rank correlation with p-value in parenthesis.

(d) The differentiation in small and large firms is based on the answering categories of item (1) in this Table. Thus, small firms are those companies with a volume of asset under management of less than 20 billion \$ (encodings 1-3), large firms are those with a volume of asset under management of more than 20 billion \$ (encodings 4-6). For Thailand small firms are defined through volume of asset under management of less than 10 billion \$ (encodings 1-2), large ones are those with asset under management of more than 10 billion $\$$ (encodings 3-4).

(e) The figures given are the z-value of the Mann-Whitney U-test and the p-value in parenthesis. $\mathrm{H}_{0}$ states that there is no difference in the use of technical analysis between the respective groups of comparison.

Stars refer to level of significance: ${ }^{*} 10 \%,{ }^{* *} 5 \%,{ }^{* * *} 1 \%$. 
TABLE 8. Beliefs about fund managers' behavior and the use of technical analysis

(1) Item: "Herding is observable amongst professional asset managers."

(2) Item: "Following the herd benefits the asset manager's career."

(3) Item: "I generally follow the trend."

[(4) Item: "People are not machines; thus security prices are clearly more determined by psychological influences than by fundamentals."]

\begin{tabular}{|c|c|c|c|c|c|c|c|}
\hline \multirow[t]{2}{*}{ Panel A } & \multirow{2}{*}{$\begin{array}{l}\text { Response } \\
\text { category } \\
\text { (a) }\end{array}$} & \multicolumn{5}{|c|}{ Descriptive statistics } & \multirow[b]{2}{*}{ ALL } \\
\hline & & US & GER & $\mathrm{CH}$ & ITA & THAI & \\
\hline $\begin{array}{l}\text { (1) Herding amongst profession- } \\
\text { als }\end{array}$ & Mean & 2.2 & 2.3 & 2.2 & 2.5 & 2.9 & 2.4 \\
\hline (2) Herding benefits career & Mean & 4.2 & 3.9 & 3.6 & 4.2 & 3.7 & 4.0 \\
\hline (3) Follow the trend & Mean & 4.4 & 3.7 & 4.0 & 3.9 & 3.3 & 3.8 \\
\hline $\begin{array}{l}\text { [(4) Dominance of psychological } \\
\text { influences on prices] }\end{array}$ & Mean & 3.2 & 2.8 & 2.7 & 3.0 & 3.3 & 3.0 \\
\hline
\end{tabular}

PANel B

(1) No herding amongst professionals

(2) Herding does not benefit career

(3) Do not follow the trend

[(4) No dominance of psychological influences]
Coefficients of rank correlation between statements of behavior and technical analysis ${ }^{\text {(b) }}$

\begin{tabular}{cccccc}
\hline US & GER & CH & ITA & THAI & ALL \\
0.047 & $-0.148^{* *}$ & -0.081 & -0.140 & $-0.161^{*}$ & $-0.115^{* * *}$ \\
$(0.574)$ & $(0.017)$ & $(0.625)$ & $(0.149)$ & $(0.074)$ & $(0.003)$ \\
$-0.272^{* * *}$ & $-0.220^{* * *}$ & -0.006 & 0.104 & -0.130 & $-0.160^{* * *}$ \\
$(0.001)$ & $(0.000)$ & $(0.974)$ & $(0.288)$ & $(0.152)$ & $(0.000)$ \\
$-0.309^{* * *}$ & $-0.329^{* * *}$ & -0.151 & $-0.268^{* * *}$ & $-0.322^{* * *}$ & $-0.335^{* * *}$ \\
$(0.000)$ & $(0.000)$ & $(0.367)$ & $(0.006)$ & $(0.000)$ & $(0.000)$ \\
$-0.257^{* * *}$ & $-0.261^{* * *}$ & $-0.371^{* *}$ & $-0.236^{* *}$ & $-0.289^{* * *}$ & $-0.321^{* * *}$ \\
$(0.002)$ & $(0.000)$ & $(0.020)$ & $(0.014)$ & $(0.001)$ & $(0.000)$
\end{tabular}

(a) There are 6 answering categories, ranging from "agree completely" (coded as 1) to "disagree completely" (coded as 6 ). Thus, a mean of 3.5 or less indicates rather approval to the statement. $\mathrm{N}$ is the number of responses.

(b) The figures given are the coefficient of the Spearman rank correlation with p-value in parenthesis.

Stars refer to level of significance: ${ }^{*} 10 \%,{ }^{* *} 5 \%,{ }^{* * *} 1 \%$. 
TABLE 9. Fund managers' characteristics and the use of technical analysis

Coefficients of multivariate orderd probit regression with the use of technical analysis (ALL fund managers) ${ }^{(\mathrm{e})}$

\begin{tabular}{|c|c|c|c|c|}
\hline & (1) & (2) & (3) & (4) \\
\hline Larger firm size ${ }^{(a)}$ & $\begin{array}{l}-0.044 \\
(0.140)\end{array}$ & $\begin{array}{l}-0.045 \\
(0.123)\end{array}$ & $\begin{array}{c}-0.065^{* *} \\
(0.036)\end{array}$ & $\begin{array}{l}-0.073 * \\
(0.053)\end{array}$ \\
\hline More time for research ${ }^{(a)}$ & $\begin{array}{c}-0.014 * * * \\
(0.002)\end{array}$ & $\begin{array}{c}-0.014 * * * \\
(0.002)\end{array}$ & $\begin{array}{c}-0.014 * * * \\
(0.003)\end{array}$ & $\begin{array}{l}-0.010 * \\
(0.092)\end{array}$ \\
\hline $\begin{array}{l}\text { No herding amongst } \\
\text { professionals }^{(\mathrm{b})}\end{array}$ & $\begin{array}{c}0.001 \\
(0.986)\end{array}$ & & & \\
\hline $\begin{array}{l}\text { Herding does not benefit } \\
\text { career }^{(\text {b) }}\end{array}$ & $\begin{array}{l}-0.053 \\
(0.204)\end{array}$ & & & \\
\hline Do not follow the trend ${ }^{(b)}$ & $\begin{array}{c}-0.180 * * * \\
(0.000)\end{array}$ & $\begin{array}{c}-0.194 * * * \\
(0.000)\end{array}$ & $\begin{array}{c}-0.189 * * * \\
(0.000)\end{array}$ & $\begin{array}{c}-0.164 * * * \\
(0.002)\end{array}$ \\
\hline $\begin{array}{l}\text { No dominance of psycholog- } \\
\text { ical influences }{ }^{(b)}\end{array}$ & $\begin{array}{c}-0.176^{* * *} \\
(0.000)\end{array}$ & $\begin{array}{c}-0.184 * * * \\
(0.000)\end{array}$ & $\begin{array}{c}-0.181 * * * \\
(0.000)\end{array}$ & $\begin{array}{c}-0.146^{* * * *} \\
(0.006)\end{array}$ \\
\hline Higher age $^{(\mathrm{c})}$ & & & $\begin{array}{l}-0.046 \\
(0.426)\end{array}$ & $\begin{array}{c}0.026 \\
(0.708)\end{array}$ \\
\hline More experience ${ }^{(c)}$ & & & $\begin{array}{c}0.009 \\
(0.844)\end{array}$ & $\begin{array}{c}0.017 \\
(0.759)\end{array}$ \\
\hline Better education $^{(\mathrm{c})}$ & & & $\begin{array}{c}0.035 \\
(0.656)\end{array}$ & $\begin{array}{l}0.005 \\
(0.964)\end{array}$ \\
\hline More senior position ${ }^{(\mathrm{c})}$ & & & $\begin{array}{c}0.065 \\
(0.113)\end{array}$ & $\begin{array}{l}-0.013 \\
(0.816)\end{array}$ \\
\hline $\begin{array}{l}\text { Comparatively worse } \\
\text { achievement }^{(\mathrm{d})}\end{array}$ & & & & $\begin{array}{c}0.088 \\
(0.140)\end{array}$ \\
\hline $\begin{array}{l}90 \% \text { width of EuroStoxx } 50 \\
\text { forecast }^{(\mathrm{d})}\end{array}$ & & & & $\begin{array}{c}-0.461 * * \\
(0.016)\end{array}$ \\
\hline Country dummies & yes & yes & yes & yes \\
\hline Pseudo R-squared & 0.058 & 0.057 & 0.060 & 0.066 \\
\hline
\end{tabular}

\footnotetext{
(a) Items are taken from Table 7, (b) Table 8, (c) Table 5 and (d) Table 6 respectively.

(e) The figures given are the coefficient of the orderd probit regression with $\mathrm{p}$-value in parenthesis.

Stars refer to level of significance: ${ }^{*} 10 \%,{ }^{* *} 5 \%,{ }^{* * *} 1 \%$.
} 